\title{
TURISMEMORFOSIS SEBAGAI PERKEMBANGAN PARIWISATA DI BADUNG, BANYUWANGI DAN LUWU TIMUR
}

\author{
I.G.A.O. Mahagangga ${ }^{1}$, I Putu Anom ${ }^{2}$, I Made. Kusuma Negara ${ }^{3}$ \\ Email: okamahagangga@unud.ac.id ${ }^{1}$,putuanom@unud.ac.id ${ }^{2}$, kusuma.negara@unud.ac.id ${ }^{3}$ \\ 1,2Program Studi Pariwisata, Fakultas Pariwisata, Universitas Udayana \\ ${ }^{3}$ Program Studi Industri Perjalanan Wisata, Fakultas Pariwisata, Universitas Udayana
}

\begin{abstract}
The tourism development in many tourism destination appears to ignore history. Geneology or social record as a history of the formation of existing conditions is considered less important. This study try to understand by apply the tourimsmorphosis concept in Badung, Banyuwangi and East Luwu. Tourismmorphosis as the evolution of tourism can be both progress and regress as an inevitable change. Consisting of the introductory stage, the reaction stage, the institutionalization stage and the compromise stage. The research paradigm is qualitative with qualitative methods and techniques, hermeneutic data analysis techniques and thick descriptive data presentation. The research results understanding that Badung was at the compromise stage, Banyuwangi at the institutional stage and East Luwu at the introductory stage. Hence, the consider of research findings could be used as a basis for future tourism development.
\end{abstract}

\begin{abstract}
Abstrak: Pengembangan pariwisata suatu daerah tampak banyak bersifat ahistori. Geneologi atau rekaman sosial sebagai sejarah terbentuknya kondisi eksisting dianggap kurang penting. Penelitian ini berupaya mengaplikasikan konsep turismemorfosis di Badung, Banyuwangi dan Luwu Timur. Turismemorfosis sebagai evolusi pariwisata dapat bersifat progress maupun regress sebagai perubahan yang tidak terelakkan. Terdiri dari tahap perkenalan, tahap reaksi, tahap pelembagaan dan tahap kompromi. Paradigma penelitian adalah kualitatif dengan metode dan teknik kualitatif, teknik analisis data hermeneutika dan penyajian data secara deskriptif mendalam. Hasil penelitian menunjukkan bahwa Badung telah berada pada tahap kompromi, Banyuwangi pada tahap pelembagaan dan Luwu Timur pada tahap perkenalan. Hasil penelitian akan sangat bijak untuk digunakan sebagai dasar pengembangan pariwisata kedepan.
\end{abstract}

Keywords: development; evolution; tourismmorphosis. 


\section{PENDAHULUAN}

Perkembangan pariwisata Indonesia, sudah tidak diragukan memberikan banyak manfaat. Tetapi masih sangat minim penelitian-penelitian ilmiah tentang perkembangan pariwisata. Penelitianpenelitian pariwisata lebih banyak mengarah kepada pengembangan pariwisata yang dianggap lebih memenuhi syarat dalam perencanaan suatu destinasi wisata maupun daya tarik wisata

Seperti penggunaan teori TALC dari Butler (1980) yang harus diakui masih di ranah ambigu bagi banyak peneliti pariwisata di Indonesia. Terdapat anggapan bahwa teori tersebut adalah berangkat dari kondisi eksisting untuk melihat posisi suatu destinasi wisata. Butler sangat menyayangkan banyak peneliti pariwisata yang mengesampingkan proses dan bersifat ahistori (Butler, 2015).

Tampak perencanaan pariwisata fisik maupun non fisik selain diperlukan pengukuran, patut diperhatikan deskripsi, proses, dan interpretasi tentang keberadaaan destinasi wisata. Masa lalu menjadi penting sebagai pelajaran dan eksistensi masa kini dan akan menentukan arah pembangunan maupun pengembangan pariwisata di masa depan.

Jika hal ini dapat dipahami oleh para perencana pariwisata, akan melahirkan tren perencanaan pariwisata dan pengembangan pariwisata berbasis pada perkembangan pariwisata. Ketika suatu destinasi wisata akan melakukan pengembangan maka tidak hanya mengikuti tren wisata dunia, pasar yang sangat kompetitif dan peran investor luar yang kuat mempengaruhi pembentukan produk wisata di tingkat lokal (dimana ada gula disana ada semut). Sumber daya pariwisata dapat secara lebih eksplisit dan logis dipandang berpeluang atau memiliki potensi pariwisata. Pengembangan pariwisata menjadi sesuai dengan kelokalan, memiliki daya tahan, memperhatikan ambang batas dan diharapkan mampu mewujudkan keharmonisan sebagai sustainable tourism development yang tidak hanya di atas kertas.

Penelitian ini adalah adalah upaya aplikasi dari konsep dan model turismemorfosis temuan Anom (dkk., 2017) yaitu perkembangan pariwisata yang dimulai dari tahap perkenalan, tahap reaksi, tahap pelembagaan dan tahap kompromi. Setiap tahap memiliki unit analisis yaitu periode, paradigma, diskursus/wacana, aktor dan institusi penopang (Anom, dkk., 2016; Anom, dkk., 2017; Mahagangga, dkk., 2018).

Turismemorfosis terinspirasi dari teori perkembangan pariwisata oleh Greenwood (1972), model organic destination area life cycle dan dimensi sosial budaya pariwisata oleh Noronha (1977; 1979), tourist area cycle of evolution dari Butler (1980), dimensidimensi pariwisata (Fridgen, 1991), mediamorfosis (Fidler, 1997), dampak pariwisata dari Raharjo dan Munandar (1998), aspek positif dan aspek negatif pariwisata (Pitana, 2002), pariwisata budaya (Geria, 2000), pariwisata budaya dan budaya pariwisata (Picard, 2006), paradigma (Ritzer, 1975 dalam Karsidi, 2001), periodisasi dalam ilmu sejarah (Nordholt, dkk, 2008), evolusi paradigmatik (Wijayanto, 2013) dan teori genealogi sebagai diskursus, institusi dan ketokohan (Foucault, 1954 dalam Arief, 2009).

Beberapa penelitian yang pernah menggunakan konsep dan model turismemorfosis, pertama Perkembangan Desa Bongkasa Menuju Desa Wisata (Aplikasi Model Turimemorfosis) oleh Dipadewanda (2018). Kedua, Perkembangan Wisata Mendaki di Gunung Agung oleh Hutabarat (dkk., 2019). Ketiga, Perancangan Website Sosiohistori Pariwisata Bali oleh Jati (2019). Keempat, Fenomena Masa Jeda Pariwisata Bali oleh Mahagangga, ( dkk., 2020).

Penelitian ini bukan studi perbandingan melainkan mengarah kepada penelitian eksploratif melihat dan memaknai perkembangan pariwisata. Asumsinya, kabupaten Badung telah berkembang, kabupaten Banyuwangi sedang berkembang dan kabupaten Luwu Timur yang baru akan berkembang pembangunan pariwisatanya.

Perkembangan yang dimaksud berbeda dengan pengembangan pariwisata yang lebih terkait dengan upaya perencanaan melahirkan strategi dan program kerja. Meskipun terdapat kemungkinan dalam perkembangan mencakup pengembangan atau perencanaan yang telah dilakukan dan tercatat sebagai rekamanrekaman sosial. Jika disepakati merujuk kepada perkembangan ilmu pariwisata dan ilmu sosial-humaniora lainnya bahwa tidak terlalu ketat dalam melihat dinamika, progress 
maupun regress, perubahan, perkembangan, dan pengembangan tampaknya dapat dikategorikan sebagai evolusi (Mahagangga, dkk., 2018).

Hasil penelitian diharapkan secara akademis mampu menambah perangkat konseptual teoritis (metodologi) ilmu pariwisata di Indonesia dan secara praktis dapat menjadi alternatif bagi para perencana pariwisata serta stakeholders (termasuk penggiat pariwisata lokal) dalam perencanaan pembangunan-pengembangan pariwisata.

\section{METODE}

Pendekatan transdisipliner (anthro-sociotourism) yang berfokus kepada ideologi masih minim dilakukan dalam penelitian pariwisata. Melalui pendekatan yang mengungkap ideologi akan mampu menemukan makna di balik fenomena (Anom, dkk., 2020). Penelitian menggunakan paradigma penelitian kualitatif, metode kualitatif, dan teknik-teknik kualitatif (Goodson, dkk., 2004; Richards, dkk., 2010; Jennings, 2018; Anom, dkk., 2020).

Sumber data yang digunakan adalah data primer dan data sekunder (Moleong, 2005). Jenis data berupa data kuantitatif dan data kualitatif (Sugiyono, 2005). Teknik penentuan informan menggunakan purposive sampling (Koenjaraningrat, 1997). Teknik pengumpulan data menggunakan observasi (Bachtiar dalam Koenjaraningrat, 1983), teknik wawancara (Jenning, 2005) dan penelitian pustaka (Zed, 2004). Teknik analisis data menggunakan hermeneutika sebagai upaya penafsiran (Dreyfus, 1982; Sugiharto, 1996; Cheong, dkk., 2000; Pernecky, dkk., 2010; Goolaup, dkk., 2018). Teknik penyajian data dilakukan secara thick description sebagai ciri khas penelitian kualitatif naturalistik (Geertz, 1973).

Model turismemorfosis digunakan sebagai kerangka pengumpulan data, fokus penelitian dan analisis data. Turismemorfosis sebagai perkembangan pariwisata suatu destinasi wisata dan daya tarik wisata terdiri dari tahap perkenalan, tahap reaksi, tahap pelembagaan dan tahap kompromi. Masingmasing tahapan tersebut memiliki periode, paradigma, aktor, wacana, dan institusi penopang.

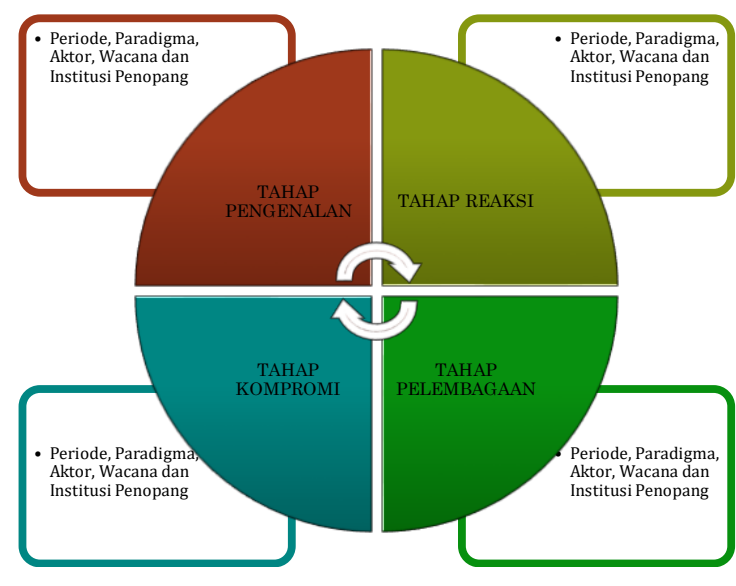

Diagram 1 Model Perkembangan Pariwisata (Turismemorfosis)

Sumber: Modifikasi Anom, dkk., 2017 dan Mahagangga, dkk., 2018

Penelitian Turismemorfosis sebagai perkembangan pariwisata di Badung, Banyuwangi dan Luwu Timur berupaya mengaplikasikan konsep dan model seperti pada Diagram 1 di atas. Temuan penelitian diharapkan mendeskripsikan periode, paradigma, aktor, wacana, dan institusi penopang secara eksplisit maupun implisit. Penafsiran (interpretasi) dilakukan secara simultan terhadap hasil observasi, hasil wawancara, hasil riset pustaka yang berdinamika dan berupaya menekan subyektifitas (penguasaan konsep dan teori, aplikasi metode kualitatif dengan memperhatikan proses-bukan sekedar hasil dan kepekaan dalam interpretasi).

\section{HASIL DAN PEMBAHASAN Turismemorfosis di kabupaten Badung}

Sejarah Badung memiliki kompleksitas yang menantang bagi para sejarawan, antropolog, sosiolog dan pemerhati budaya. Selama ini sejarah kabupaten Badung dikenal kerajaan Denpasar dan kerajaan Kesiman sebagai penguasa wilayah Badung sejak kekalahan Puputan Mengwi (runtuhnya kerajaan Mengwi) tahun 1891 (beberapa sumber menyatakan kerajaan Mengwi telah lemah kekuasaannya sejak tahun 1850). Selain itu, sejarah kerajaan Mengwi sangat berkaitan dengan kerajaan Blambangan ketika Raja Mengwi I dan Raja Mengwi II menguasai wilayah ujung timur pulau Jawa tersebut (tahun 1700-an). 
Setelah perang Puputan Badung tahun 1906 barulah keadaan dipandang kondusif oleh pemerintah kolonial Belanda. Mulai dilakukan pembangunan infrastruktur dan mulai dipikirkan fokus pembangunan di Bali (termasuk Badung). Kekaguman terhadap kebudayaan Bali yang dianggap sebagai asli nusantara dan geografis pulau Bali yang kecil kemungkinan mendorong pariwisata menjadi pilihan sebagai sumber pemasukan bagi pemerintah kolonial Belanda. Termasuk sebelum perang dunia I di Eropa terdapat trend berwisata ke luar negeri.

Tahun 1912 tampak pemerintah kolonial Belanda sudah mulai membuka Singaraja dan daerah lain termasuk Badung sebagai obyekobyek wisata (transportasi laut, darat dan akomodasi sudah mulai di bangun). Guiding book muncul tahun 1913 hanya 5 tahun setelah kepulauan Indonesia diduduki di bawah Pax Neerlandica (yang terakhir dikalahkan melalui perang Puputan Klungkung 1908). Buku panduan tersebut mencakup Jawa Barat, Jawa Tengah, Bali, Lombok, Sumatera Utara, Toraja dan Banten (Nugraha, 2000; Nugraha, 2006).

Kabupaten Badung memiliki wilayah seperti senjata tradisonal keris, padat di wilayah selatan dan mengecil di wilayah utara. Badung selatan tidak asing lagi bagi wisatawan karena memiliki banyak daya tarik wisata, kawasan wisata, akomodasi dan fasilitas pendukung pariwisata Bali banyak di Badung Selatan (pantai Kuta, Nusa Dua, kawasan pura Uluwatu, Jimbaran dan banyak lainnya). Wilayah Badung Utara adalah pegunungan dengan lahan pertanianperkebunan. Alam pegunungan dan budaya agraris seperti subak di zaman moderen (atau mungkin postmodern?) masih dapat disaksikan sebagai living culture oleh wisatawan.

Tetapi harus diakui perkembangan pariwisata di Badung Utara lebih lambat daripada di Badung Selatan. Secara geneologi, beberapa daya tarik wisata di Badung Utara sebenarnya memiliki riwayat pariwisata sejak era kolonial Belanda. Ada yang mampu bertahan, bertahan dengan pengembangan jenis wisata berbeda, dan ada yang tidak berlanjut. Seperti areal luar pura Taman Ayun Mengwi, Sangeh, Bongkasa, Sempidi, Lukluk, Darmasaba, Blahkiuh dan Plaga.

Serupa dengan kota Denpasar yang dahulu menjadi satu wilayah dengan kabupaten Badung sampai tahun 1970-an. Beberapa daya tarik wisata yang kuat memiliki geneologi sejak era pemerintah kolonial ada yang masih bertahan seperti pantai Sanur, Museum Bali, Bali Hotel dan yang lainnya (beberapa pusat atraksi wisata yaitu pentas seni tampaknya tidak berlanjut seperti di Tanjung Bungkak, Sesetan dan Belaluan). Keberadaan Bali Hotel di jalan Veteran kota Denpasar saat era pemerintah kolonial Belanda mendorong kelahiran banyak art shop dan penginapan di jalan Gajah Mada, Gemeh, Titih, Tampak Gangsul, Belaluan dan sekitar Puri Satria / Pasar Burung (di era pandemi covid-19 tahun 2020 tampak banyak yang membuka kafe/kedai kopi dengan sasaran pengunjung remaja di sekitar areal Bali Hotel seperti di jalan Kaliasem, Jalan Durian, Jalan Karna, dan Jalan Arjuna).

Setiap tahap turismemorfosis di kabupaten Badung, memiliki periode, paradigma, diskursus / wacana, aktor dan institusi penopang. Turismemorfosis di Kabupaten Badung menunjukkan bahwa perkembangan pariwisata pada masa awal tidak lepas dari peran pemerintah kolonial Belanda, seniman-ilmuwan sosial-budaya asing, pemerintah pusat, pemerintah daerah, pengusaha yang memiliki jaringan di pusat dan perusahaan jejaring global, disamping lokal. Mulai dari tahap perkenalan (19121919), tahap reaksi (1930-1938), tahap pelembagaan I (1950-1968), tahap pelembagaan II (1969-1990), tahap pelembagaan III (1991-2011) dan tahap kompromi tahun 2012 sampai sekarang.

Pada tahap pelembagaan III (1991-2011), di era Menteri Pariwisata RI I Gde Ardika (2000-2004), tampak peran masyarakat lokal dalam pembangunan pariwisata mulai difokuskan. Hal ini sejalan dengan wacana pembangunan pariwisata berkelanjutan, community based tourism (cbt), ecoturism, agrotourism dan desa wisata (sebelumnya antara tahun 1990-2000, di era bupati Badung Alit Putra sudah diupayakan pengembangan desa wisata di Badung Utara yaitu di desa Lawak, Plaga dan desa Baha, Mengwi tetapi yang di desa Baha tampak tidak berhasil).

Sangat sulit melakukan keseimbangan pembangunan pariwisata antara Badung Selatan yang sangat maju, sementara Badung Utara masih tertinggal). Pada tahap pelembagaan III (1991-2011), mulai dirintis 
pengembangan daya tarik wisata di tingkat desa dengan menggandeng travel agent. Seperti di Sangeh (daya tarik wisata alam), Mengwi (wisata puri dan areal jaba Pura Taman Ayun), Bongkasa (wisata puri dan rafting) dan beberapa desa lain.

Termasuk saat kepemimpinan bupati Badung Anak Agung Gde Agung selama 2 periode (2005-2015), peralihan dari tahap pelembagaan III (1991-2011) ke tahap kompromi (2012-sekarang). Sulit direalisasikan pemerataan pembangunan Badung Selatan dan Badung Utara. Wilayah Badung Utara direncanakan untuk pengembangan pariwisata alternatif (ecoturism, agorwisata dan sejenisnya) tetapi masyarakat lokal berkeinginan untuk mass tourism (supaya sama dengan di Badung Selatan keramaian wisatawan dan dibayangkan akan memiliki pemasukan ekonomi yang tinggi).

Kemudian, investor luar mulai memasuki wilayah Badung Utara untuk pengembangan pariwisata sesuai trend pasar (meskipun terdapat beberapa bisnis pariwisata di Badung Utara yang memperhatikan cbt tetapi sangat sedikit). Melalui sistem kerjasama bagi hasil, sewa tanah, dan sejenisnya dibuka daya tarik wisata yang mampu menarik kedatangan wisatawan secara masif (selfie, swing, dan sejenisnya). Banyak potensi wisata lokal (terutama wisata budaya) yang terabaikan karena dianggap lebih menjanjikan perpaduan wisata alam dan wisata buatan (lebih cepat dan mudah mendatangkan "dollar").

Tahun 2016 terpilih bupati Badung I Nyoman Giri Prasta yang dikenal sangat spektakuler. Bupati "bares" (pemurah dan tidak pelit) ini, adalah politisi dari PDI-P yang sebelumnya menjabat sebagai Ketua DPRD Badung. Bupati Giri Prasta dikenal dekat dengan warga pedesaan dan memiliki kebijakan-kebijakan seperti bantuan hibah dalam jumlah besar bagi masyarakat (bahkan bagi masyarakat di luar kabupaten Badung). Menurut Bupati Giri Prasta, kesejahterahaan masyarakat Badung adalah yang utama. Hibah dan bantuan bagi masyarakat Badung bersifat no limit asalkan memiliki kajian dan tidak melanggar hukum Meskipun di tahun 2018, bupati Badung meng-klaim telah menuntaskan seluruh janji kampanyenya, tetapi secara empiris tampak pemerataan pembangunan wilayah Badung Selatan dan Badung Utara terutama pembangunan sektor pariwisata belum terwujud (memberikan perhatian material secara nyata bagi masyarakat Badung Utara yang merupakan wilayah pedesaanpertanian adalah upaya pemerataan pembangunan ala Giri Prasta).

Kabupaten Badung yang memiliki Pendapatan Asli Daerah (PAD) paling tinggi di provinsi Bali bersumber dari Pajak Hotel dan Restoran dan retribusi pariwisata lainnya. Pantai Kuta, pantai Nusa Dua, bandara internasional Ngurah Rai, puluhan pantai di wilayah Badung Selatan serta akomodasi wisata merupakan kondisi eksisting yang tidak terlepas dari geneologi mulai tahap perkenalan dari turismemorfosis.

Pada tahap kompromi (2012-sekarang) tampak jelas, bahwa jenis atau tipe pariwisata apa pun (padahal pariwisata budaya adalah core) dapat dilakukan. Terjadi persebaran pusat pariwisata dari Kuta ke wilayah Selatan selain Nusa Dua dan Uluwatu yang sebelumnya sudah dikenal wisatawan (pantaipantai dan tebing-tebing di bawah Bukit Jimbaran dan dari Kuta ke Utara seperti Seminyak, Canggu, Munggu dan sekitarnya).

Di tahap kompromi, pertumbuhan ekonomi secara kewilayahan dan kesejahterahaan masyarakat lokal adalah tujuan utama. Ketika terdapat sesuatu jenis wisata yang sebenarnya tidak sesuai secara budaya atau pengembangan destinasi wisata seperti (pembangunan daya tarik wisata baru, pembangunan villa, atraksi wisata yang tidak sesuai kelokalan dan sejenisnya) yang melanggar/berpotensi merusak lingkungan/budaya dapat terealisasi ketika terjadi kompromi. Asalkan tidak mengganggu esensi dari masyarakat yaitu agama Hindu dan tradisi adat-istiadat (terindikasi kompromi terjadi dengan berupaya menghegemoni aktoraktor lokal yang terkait dengan agama dan tradisi). Tahap kompromi pariwisata di kabupaten Badung terkait erat dengan kompensasi-kompensasi yang tidak selalu bersifat material/ekonomi, tetapi dapat berupa kompensasi sosial, kompensasi budaya, dan kompensasi politik.

Tetapi terdapat hal mengejutkan pada beberapa desa adat/pekraman di Badung Selatan yang mulai menunjukkan eksistensinya. Pengalaman bekerja di industri jasa pariwisata, berkaca dari dunia luar dan digunakannya daerahnya sebagai daya atarik 
wisata selama puluhan tahun mendorong untuk kreatif dan mandiri memanfaatkan sumber daya pariwisata sebagai potensi pariwisata yang diwujudkan menjadi daya tarik wisata perpaduan antara budaya, alam dan buatan. Tampak pemerintah kabupaten Badung tertinggal dalam hal ini karena tanpa diduga daya tarik wisata-daya tarik wisata ini mampu mengundang banyak wisatawan dan pengunjung (sebagai contoh pantai Pandawa dan Pantai Melasti).

Kabupaten Badung berada di tahap kompromi dengan serangkaian pembangunan pariwisata kompleks dengan ragam problematika. Prediksi Kabupaten Badung selanjutnya akan disesuaikan dengan dimensi pariwisata di masa depan. Tahap kompromi menekankan seperti "apapun bisa dilakukan untuk pariwisata" dalam arti positif (maupun negatif) bahwa pariwisata memiliki peran sentral sebagai penggerak sektor-sektor lain. Jika pariwisata menemui krisis, maka akan mengganggu sektor lain dan kehidupan masyarakat Badung. Ketergantungan pada pariwisata di Kabupaten Badung kedepannya bukan sekedar asumsi, hipotesis atau sekedar dugaan melainkan fakta yang harus dipahami untuk keberlangsungan sektor pariwisata dan kesejahteraan masyarakat Badung mengingat keterbatasan sumber daya (manusia, alam, lingkungan).

Anugrah kepada kabupaten Badung dan hampir seluruh kabupaten/kota di Bali adalah pariwisata berkembang pesat oleh keunikan budaya, budaya berbeda (living culture), cultural landscape, dan living monument sebagai modal yang mampu menarik kedatangan wisatawan. Perencanaan mungkin sudah diupayakan sejak era pemerintah kolonial Belanda, tetapi harus diakui sektor pariwisata berkembang tidak terduga yang mendahului dari upaya perencanaan dari pemerintah daerah. Faktor eksternal sangat menentukan yang melahirkan kemampuan adaptif masyarakat untuk responsif, bertahan dan inovatif dalam pembangunan maupun pengembangan pariwisata.

Pandemi Covid-19 tahun 2020 telah memberikan pelajaran berharga bagi seluruh umat manusia di dunia. Sudah waktunya untuk memikirkan kembali kebijakan pariwisata dengan mempertimbangkan ragam dimensi pariwisata. Aspirasi dimensi sosial budaya merupakan salah satu pertimbangan seperti turismemorfosis.

Turismemorfosis di Kabupaten Badung menunjukkan bahwa perkembangan pariwisata dari tahap perkenalan sampai tahap kompromi tidak terlepas dari faktor eksternal. Mulai dari pemerintahan kolonial Belanda, pemerintah Indonesia, jaringan bisnis Jakarta dan konglomerat global. Dilihat dari faktor internal, peran aktor lokal selalu bertahan dengan strategi adaptif.

Sehingga jika diharapkan pembangunan pariwisata berkelanjutan terwujud (dengan meminimalkan tujuan laten), harus terdapat kekuatan eksternal untuk mempengaruhinya. Seperti UNWTO, konglomerat global, jaringan tour operator global, dan pemerintah pusat. Evolusi yang positif dapat terjadi karena dengan pengaruh faktor eksternal yang kuat maka secara internal Pemerintah Badung, pelaku pariwisata dan masyarakat tentunya akan beradaptasi.

Stakeholders pariwisata harus memahami hal ini sehingga pariwisata di kabupaten Badung dan mungkin pariwisata di provinsi Bali mampu secara sungguh-sungguh melaksanakan pembangunan pariwisata secara berkelanjutan. Sudah saatnya aspek ekonomi, aspek lingkungan dan aspek sosial berjalan harmoni (filosofis Tri Hita Karana sebenarnya sudah mencerminkannya).

\section{Turismemorfosis di kabupaten Banyuwangi}

Bumi Blambangan (Banyuwangi) sudah dikenal oleh bangsa asing sejak ratusan tahun lalu. Hal ini kemungkinan disebabkan karena letak strategis di ujung timur pulau Jawa digunakan sebagai tempat persinggahan (transit). Catatan sejarah menunjukkan di era kepemimpinan Gusti Ketut Kaba-Kaba dan Gusti Ketut Beda sebagai perwakilan Kerajaan Mengwi di Blambangan (1765-1767) sudah membuka perdagangan internasional (Margana, 2012 dalam Maria 2017).

Saudagar dan pelaut dari Eropa terutama Inggris (terindikasi kamar dagang Kerajaan Inggris EIC sebagai saingan VOC sudah masuk Blambangan, Denmark dan Portugis sudah ramai berdatangan. Tetapi situasi ini berbeda ketika melihat laporan tahun 1805 yang menyatakan keadaan Blambangan waktu itu sangat tidak layak. Sulit ditemui orang asli Blambangan (tersebar di pegunungan-cikal bakal disebut suku Osing), bencana gunung 
meletus dan wabah / sanitasi lingkungan yang buruk (Stockdale, 2017).

Hal ini disebabkan setelah penggulingan kekuasaan Gusti Ketut Kaba-Kaba dan Gusti Ketut Beda karena dianggap tidak cakap memerintah. Terjadi perang Puputan Bayu pada tanggal 18 Desember 1771 antara VOC dan Laskar Blambangan yang dipimpin oleh bangsawan Blambangan pangeran Jagapati (Mas Rempeg) dan Sayu Wiwit (Lekkerkerker, 1923).

Sebelumnya Wong Agung Wilis dan putranya pangeran Puger telah memberikan perlawanan. Wong Agung Wilis adalah seorang bangsawan perwira Blambangan yang sebenarnya memiliki peluang untuk menjadi Raja tetapi puas dengan posisi sebagai penasehat Gusti Ketut Kaba-Kaba dan Gusti Ketut Bedha. Wong Agung Wilis keturunan Raja Besar Blambangan Prabu Tawang Alun yang beragama Hindu dan memiliki kekuasaan hampir $3 / 4$ wilayah Provinsi Jawa Timur saat ini tahun 1600-an. Wilayah kekuasaan Prabu Tawang Alun sudah menjadi "incaran" sejak era Sultan Agung sampai Pakubuono II yang menggandeng $V O C$ sampai meletusnya Puputan Bayu. Wong Agung Wilis memiliki hubungan dekat dengan Raja Mengwi dan Raja Klungkung. Terdapat dugaan bahwa Ibundanya berasal dari Puri Klungkung dan memiliki hubungan dengan Puri Kaba-Kaba (Permaisuri Raja Mengwi yang menguasai Kerajaan Blambangan saat itu berasal dari Puri Kaba-Kaba).

Penaklukan Blambangan membawa implikasi negatif seperti penghapusan tradisi budaya lokal demi kelanggengan penguasa. Setelah perang Puputan Bayu banyak warga Blambangan tidak berani mengaku sebagai orang Blambangan, menjalankan tradisi, kesenian dan warisan budaya leluhurnya. Banyuwangi moderen adalah pewarisan dari sejarah di masa lalu tersebut (Beatty, 2012).

Wisatawan pertama yang datang menandakan dimulainya tahap perkenalan I (1805-1930) dari turismemorfosis di Kabupaten Banyuwangi. Ditandai dengan kedatangan rombongan Jendral $M$. Tombe atas undangan acara kelahiran putra pertama Komandan Pasukan Belanda Blambangan Wikerman yang beristrikan seorang bangsawan Melayu. Para tamu tersebut tidak menemukan budaya yang khas dari kesenian Blambangan (Stockdale, 2017). Tetapi tahap perkenalan I (1805-1930) tersebut sangat lambat perkembangannya. Pasalnya, pemerintah kolonial Belanda saat itu memfokuskan pada hasil perkebunan, pertanian dan pelabuhan untuk sektor perdagangan internasional.

Tahap perkenalan II (1950-2000) juga memiliki rentang waktu yang cukup lama. Berdasarkan geneologi, pariwisata kabupaten Banyuwangi mulai dikenal keunikannya. Terutama wisata alam berawal dari kedatangan peneliti Eropa di Kawah Ijen dan penggunaan belerang untuk industri mulai era pemerintah kolonial Belanda (peneliti, fotografer, wartawan dari Prancis dan Kanada). Termasuk mulai dikenal indahnya pantai ujung timur Jawa oleh para surfer asing melalui Bali yang telah diperkenalkan oleh orang asing (Amerika Serikat, Brazil dan Australia).

Tahap perkenalan II (1950-2000), keunikan budaya lokal telah direvitalisasi, namun masih sebatas hiburan masyarakat (gandrung dan lain-lain). Tahun 1995, Bupati T. Purnomo Sidik yang dikenal sebagai "Bupati Tsunami" sudah meresmikan wisata kampung Osing di Kemiren dengan biaya mencapai 4 milyar rupiah.

Tahapan reaksi (2001-2009) ditunjukkan oleh sosok Bupati Samsul Hadi yang membentuk politik identitas budaya lokal dan mulai membuka obyek wisata waktu itu. Jika era bupati sebelumnya membangun infrastruktur (sampai sekarang masih terdapat jejaknya), berbeda dengan bupati Samsul Hadi mulai fokus terhadap sumber daya-sumber daya yang berpotensi sebagai obyek wisata (banyak berada di areal perusahaan negara seperti Perhutani dan lainnya). Aksesibilitas dan hubungan kerjasama dengan pihak-pihak berkepentingan dalam rangka pembangunan pariwisata di kabupaten Banyuwangi menjadi prioritas. Potensi wisata budaya dan potensi wisata alam dipahami merupakan modal pembangunan pariwisata kabupaten Banyuwangi.

Pada tahap pelembagaan (2010-sekarang), Upaya bupati Samsul Hadi dilanjutkan oleh Bupati Abdullah Azwar Anas yang jenius dan pekerja keras dalam merencanakan dan mengembangkan pariwisata sebagai "payung pembangunan" di Kabupaten Banyuwangi. Pada tahap pelembagaan ini Bupati Abdullah Azwar Anas telah memberikan influence semangat pariwisata di Kabupaten 
Banyuwangi dengan dukungan yang kuat dari pemerintah pusat. Peran serta aktif masyarakat mampu difasilitasi dengan koordinasi dinasdinas (OPD) kabupaten Banyuwangi (pariwisata bukan hanya tupoksi dari Dinas Pariwisata, melainkan diperlukan integrasi antar dinas dalam mewujudkan programprogram kerja sebagai action). Berdasarkan data statistik, jumlah kunjungan wisatawan domestik melonjak tajam. Pertumbuhan ekonomi di Kabupaten Banyuwangi tumbuh pesat dan diklaim telah berhasil mengembangkan sektor pariwisata. Tampak strategi branding melalui event-event terencana (dalam setahun terdapat puluhan event yang dikemas dalam Banyuwangi Festival dan Banyuwangi Ethno Carnival / $B E C$ ), perbaikan aksesibilitas, penataan fisik daya tarik wisata, peningkatan SDM, sistematisasi kelembagaan pariwisata, perangkat internet sampai pelosok desa dan "pola pembangunan terintegrasi" dengan manajemen control-evaluasi ketat membuat kabupaten Banyuwangi berkembang pariwisatanya (hampir seluruh program sektor pembangunan, pariwisata digunakan sebagai payungnya). Puluhan penghargaan dalam dan luar negeri, termasuk dari Perserikatan Bangsa-Bangsa, dimenangkan oleh Kabupaten Banyuwangi di bawah kepemimpinan Bupati Abdullah Azwar Anas.

Analisis turismemorfosis menunjukkan kabupaten Banyuwangi baru memasuki tahap pelembagaan. Tahap reaksi seperti manfaat ekonomi mulai dirasakan, terdapat persaingan, dan ketidakpuasan masih belum dapat dilewati sepenuhnya (praktisi pariwisata yang menjual paket-paket wisata terindikasi "bersaing" dengan pemkab Banyuwangi).

Tetapi faktor internal seperti peran aktor bupati Abdullah Azwar Anas berbeda dengan di kabupaten Badung yang dominan sejak awal perkembangan pariwisata didominasi oleh faktor-faktor eksternal. Dominasi faktor internal mampu menampilkan bahwa pembangunan sektor pariwisata mencapai kesuksesan. Meskipun hasilnya secara ekonomi belum memberikan dampak signifikan. Pendapatan ekonomi kabupaten Banyuwangi tetap didominasi oleh sektor pertanian, perkebunan, perikanan, kelautan dan pertambangan. Dalam memberikan pemasukan bagi daerah, pariwisata sebagai sektor jasa masih tertinggal dibanding sektor- sektor pembangunan yang telah menjadi andalan kabupaten Banyuwangi sejak dahulu (masih minim melalui pajak hotel dan restoran, retribusi pariwisata maupun sumber pendapatan lainnya dari pariwisata). Tetapi beberapa sektor meningkat diperkirakan karena pariwisata (efek domino) seperti transportasi, percetakan, jasa kontruksi, makanan dan minuman, handycraft, tekstil dan pakaian jadi.

Struktur kelembagaan dan fungsi sosial bergantung pada faktor internal dan faktor eksternal. Aksi dan reaksi di tahap pelembagaan biasanya sudah mampu menarik faktor-faktor eksternal (pemerintah pusat, investor Banyuwangi / asing, termasuk wisatawan mancanegara).

Dilema dapat terjadi, faktor politis dan faktor ekonomi tampak menjadi penentu. Masyarakat lokal mungkin dihadapkan pada pilihan sulit (sudah mulai tampak generasi muda "enggan" menjadi petani atau nelayan dan lebih "nyaman" bekerja di industri jasa). Keadaan ini masih berproses ditopang oleh minat pasar wisatawan dan daya tahan daya tarik wisata secara berkelanjutan.

Di titik ini, tampak kabupaten Banyuwangi harus waspada karena terindikasi sadar wisata masyarakat belum merata, melainkan hanya berada di lingkaran aktoraktor yang intens berhubungan dengan pemkab dan masyarakat pendukungnya (termasuk strategi branding dan pemanfaatan promosi melalui medsos karena dapat menjadi pukulan balik ketika apa yang dipromosikan ternyata fakta tidak sesuai).

Peran aktor kepala daerah menjadi sangat menentukan untuk kasus Banyuwangi. Terdapat kekhawatiran bahwa jika bupati berganti, dan penggantinya memiliki visi dan misi, kecakapan, kemampuan, dan jejaring berbeda maka perkembangan pariwisata di Banyuwangi akan melambat (sehingga secara politis bupati Banyuwangi Abdullah Azwar Anas yang sudah 2 periode harus mempersiapkan calon pengganti yang dapat melanjutkan apa yang sudah dicapai).

Oleh karena itu, ada kemungkinan Kabupaten Banyuwangi masih stagnan pada tahap pelembagaan di bidang pariwisata. Terindikasi ada perbedaan pendapat yang tajam antara aktor baru dengan elit masyarakat atau dengan masyarakat, persaingan antar komponen pariwisata yang memerlukan 
identifikasi ulang / re-formulasi sektor pariwisata, penurunan kunjungan wisatawan atau penyebab lainnya (faktor internal dan faktor eksternal). Kecuali jika pemimpin berikutnya memiliki kualitas dan kuantitas yang sama dengan Bupati Abdullah Azwar Anas dan dukungan dari pemerintah pusat juga tetap kuat, maka pembangunan pariwisata di Banyuwangi akan memasuki tahap kompromi.

Saat pandemi corona covid-19, pariwisata Banyuwangi diuji kelembagaannya. Protokol kesehatan dan pembatasan jumlah kunjungan ke daya tarik wisata diupayakan. Meskipun sepi wisatawan mancanegara, pengunjung dari kabupaten-kabupaten di Jawa Timur sangat membantu eksistensi pariwisata Banyuwangi.

Di sisi lain tampak muncul usaha-usaha baru seperti menggunakan mobil maupun motor (menjual kopi, makanan dan yang lainnya). Bisnis ini dilakukan oleh warga Banyuwangi yang semula bekerja di Bali tetapi karena sepinya wisatawan mancanegara, kemudian memilih untuk pulang ke kampung halaman.

\section{Turismemorfosis di kabupaten Luwu Timur}

Tahun 2003 Kabupaten Luwu Timur berdiri sebagai pemekaran dari kabupaten Luwu Utara (sebelumnya menjadi satu yaitu bagian dari kabupaten Luwu yang merupakan pemasok hasil pertanian, perkebunan, perikanan, kelautan dan pertambangan di Sulawesi Selatan). Berdirinya kabupaten Luwu Timur merupakan perjuangan sejak tahun 1960-an, ketika lobbying berhasil maka berdiri kabupaten Luwu Timur dengan sumber daya alam melimpah (pertanian, perkebunan, perikanan, kelautan dan pertambangan) dan tambang besi terbesar di Indonesia milik Kanada PT. INCO (sekarang PT. Vale milik Brazil) berada di wilayahnya.

Sejarah Luwu Timur tidak dapat dipisahkan dari kerajaan besar yaitu Kedatuan Luwu (istananya saat ini berada di Palopo). Kebesaran anak dari Batara Guru yaitu raja Sawerigading yang tertuang dalam kitab terpanjang di dunia yaitu $I$ La Galigo mengisahkan kebesaran, kekuasaan, religi, roman dan budaya tokoh suku Bugis tersebut.

Belum ditemukan bukti otentik tentang masa / waktu berdirinya kerajaan Luwu, tetapi di masa Majapahit jelas sudah dikenal karena tertulis di kitab Negarakertagama (Pegeaud dalam Syukur, 2015). Arkeolog Universitas Hasanuddin dan tim proyek OXIS menduga kuar Danau Matano dan sekitarnya yang memiliki kandungan nikel dan besi melimpah adalah pemasok bahan dasar senjata (pamoro luwu) bagi kerajaan Majapahit dan kerajaankerajaan lain di Nusantara (Rusdianto, 2011). Periodisasi sejarah Luwu dapat dibagi menjadi tiga yaitu Galigo, yakni fase-fase raja seperti dewa (hemelingen period), periode kedua yaitu lontara / periode To Manurung dan periode ketiga adalah periode Islam (Pelras, 1995 dalam Syukur, 2015).

Selain itu suku-suku di pegunungan juga memiliki nilai lokal dan ragam seni di masa lalu. Suku Padoe yang dikenal sebagai induk mayoritas suku di Luwu Timur berdiam di pinggir danau Matano sebagai Mokole (pusat kerajaan). Dibawah Mokole Matano (Padoe) terdapat anak-anak suku yaitu Weula, Tambie, Tanunsie, Donge, Taipa, Turea dan Karonsie. Sampai sebelum masa pemberontakan Di/TII oleh Kahar Muzakar, masih terlihat ketika ada hajatan besar seperti pernikahan di Mokole Matano maka warga dari para anak suku tersebut berdatangan dengan membawa hasil bumi dan ternak. Ketika pemberontakan DI/TII Kahar Muzakar, terjadi perusakan tinggalan budaya fisik maupun non fisik karena paham ideologi agama yang digunakan untuk mempengaruhi masyarakat. Banyak tinggalan arkeologi seperti perisai, topi perang, pedang, badik dibuang dan sejenisnya dibuang ke danau Matano. Jika ditemukan oleh Kahar Muzakar dan pengikutnya maka akan dibakar / dimusnahkan. Terjadi degradasi tradisi budaya lokal yang sulit dihindari. Syukurnya kitab $I$ La Galigo selamat dan poin-poin pentingnya masih dapat diceritakan dari generasi ke generasi sebagai rekaman sosial masa lalu.

Islam dalam hal ini menjadi bagian dari gerakan Kahar, dengan menonjolkan pemurnian Islam yang tidak kompromis terhadap tradisi bahkan termasuk mazhab. Meskipun demikian hal tersebut ternyata tidak menghilangkan kitab I La Galigo sebagai identitas dan pemersatu masyarakat Sulawesi Selatan, bahkan mungkin hampir di seluruh negeri bekas kekuasaan kerajaan Luwu seperti di Kalimantan, Gorontalo, Maluku, Filipina banyak daerah lainnya (Harvey dalam Pabajjah, 2012). 
Sosial budaya masyarakat Luwu Timur adalah perpaduan antara budaya pesisir dengan budaya pegunungan. Ditambah kedatangan para transmigran dari beberapa daerah di Indonesia menambah kemajemukan dan pluralis dengan pemersatunya adalah $I L a$ Galigo, tanah Batara Guru, dan kebesaran Sawerigading. Seperti contoh transmigran asal Bali tetap menjalankan tradisi leluhurnya di Bali seperti sebelumnya, tetapi penghormatan terhadap khasanah budaya lokal tetap terjaga menyatu sebagai orang Sulawesi (Luwu Timur, Sulawesi Selatan).

Kabupaten Luwu Timur sebenarnya sudah sempat menarik perhatian wisatawan di era 1994 yaitu di pantai Lemo (waktu itu masih kabupaten Luwu). Daya tarik wisata pantai ini menjadi tempat transit wisatawan mancanegara setelah mengunjungi Toraja dan menuju ke Palu maupun Manado. Sempat dibangun beberapa homestay (beberapa sisa bangunan masih tampak) karena wisatawan mancanegara waktu itu banyak menginap dengan length of stay 6-7 hari. Tidak diketahui mengapa wisatawan mancanegara terputus dan tidak menginap lagi di daya tarik wisata pantai Lemo.

Terdapat expatriat berasal hampir dari seluruh dunia di kabupaten Luwu Timur sebagai pekerja tambang. Tambang nikel terbesar di Indonesia yang dibangun sejak tahun 1960-an dan terletak di dekat danau terdalam di Indonesia yaitu danau Matano di Sorowako, kecamatan Nuha. Sorowako terlihat menjadi wilayah berbeda karena kawasan pertambangan. Sejak tahun 1980-an sudah berkembang persewaan, penginapan, hotel dan restoran untuk para expatriat maupun pekerja Indonesia di tambang Nikel (saat ini kawasan pemukiman bagi pekerja tambang sudah disediakan oleh pihak perusahaan).

Upaya pembangunan sektor pariwisata di Kabupaten Luwu Timur baru dimulai pada tahun 2016. Peran bupati Luwu Timur Thoriq Husler dan jajarannya termasuk beberapa anggota DPRD Luwu Timur berupaya mewujudkan pembangunan sektor pariwisata. Kesadaran akan kekayaan sumber daya alam (pantai, sungai pegunungan dan danau-danau) dan sumber daya budaya. Masyarakat pesisir dominan suku Bugis dan masyarakat pegunungan dominan suku Padoe, Karunsie, dan Tambee (serta beberapa anak suku lain) tampak mendorong mewujudkan pembangunan sektor pariwisata di kabupaten Luwu Timur (terdapat juga suku Toraja, suku Pamona yang mayoritas di Sulawesi Tengah dan suku-suku Sulawesi lainnya).

Secara sosial masyarakat Luwu Timur sangat plural. Selain warga asli (pegunungan dan pesisir), terdapat desa-desa transmigrasi (mulai tahun 1970-1980) yang sudah menyatu dengan warga masyarakat lokal. Para transmigran yang sudah memasuki generasi ke-3 berasal dari Bali, Jawa, dan daerah lainnya di Indonesia. Sektor unggulan di kabupaten Luwu Timur adalah pertanian, perkebunan, perikanan, kelautan dan pertambangan (Luwu Timur pemasok beras terbesar bagi provinsi Sulawesi Selatan).

Dalam perencanaan pembangunan dimulai dari nol dalam arti berusaha memformat pariwisata seperti apa yang akan diwujudkan. Sehingga upaya pengembangan sektor pariwisata di Kabupaten Luwu Timur menarik. Dapat bersifat spekulatif, berisiko secara ekonomi, dan kemungkinan diperlukan proses panjang kecuali terdapat faktor penarik kuat bagi wisatawan untuk datang berkunjung.

Tetapi upaya pemerintah kabupaten Luwu Timur mulai dari bupati, wakil bupati, kepala dinas pariwisata dan pemuda olah raga, sampai beberapa anggota DPRD patut mendapat apresiasi. Pembangunan sektor pariwisata diharapkan sesuai dengan potensi wisata lokal dan tidak asal mengundang investor untuk berinvestasi.

Secara turismemorfosis, kabupaten Luwu Timur berada pada tahap perkenalan mulai dari tahun 1994 ketika wisatawan mancanegara sudah mulai berkunjung ke pantai Lemo (meskipun waktu itu kabupaten Luwu Timur belum berdiri). Perkembangannya sangat lambat, karena genealogi pariwisata tampak minim di kabupaten Luwu Timur (sejak awal sektor basis adalah pertanian dan pertambangan).

Namun Luwu Timur memiliki sumber daya pariwisata yang berpotensi untuk pengembangan selanjutnya (alam dan budaya). Didukung dengan kebutuhan masyarakat akan waktu luang dan rekreasi yang tinggi, termasuk masyarakat di sekitar Kabupaten Luwu Timur (wilayah Sulawesi Selatan sangat luas dan tampak pusat-pusat hiburan terkonsentrasi di Makasar). Meskipun intensitas kedatangan wisatawan mancanegara 
sedikit, namun wisatawan mancanegara datang untuk transit sebelum ke Sulawesi Tengah atau Sulawesi Utara (setelah berwisata ke Toraja). Selain itu, mulai tampak generasi muda mulai terlihat bersemangat dan aktif terlibat dalam kegiatan pariwisata (sarana promosi melalui medsos).

Fenomena tersebut muncul prospek yang baik atau menjanjikan di masa depan, apalagi jika pemerintah daerah mampu merencanakan ke depan. Seperti pengesahan Rencana Induk Pembangunan Pariwisata Daerah / Ripparda dan peraturan/kebijakan pendapatan daerah dari pariwisata (termasuk sosialisasi tentang sadar wisata / Sapta Pesona bagi masyarakat).

Mulai tahun 2016 pengembangan pariwisata di Luwu Timur masih terfokus pada infrastruktur. Tentang fokus produk wisata dan pemasaran tampak belum disepakati. Namun dapat dipastikan di waktu mendatang, jika pemerintah daerah konsisten fokus pada pengembangan sektor pariwisata, Kabupaten Luwu Timur akan memasuki tahap reaksi. Terlebih jika aksesibilitas seperti bandara udara milik perusahaan pertambangan nikel terbesar di Indonesia PT. Vale dapat digunakan. Bentuk-bentuk CSR dari PT. Vale akan sangat membantu dengan syarat proposal yang diajukan realistis dan sesuai dengan kebutuhan masyarakat lokal.

Fokus pengembangan pariwisata disarankan pada potensi wisata alam dan potensi wisata buatan. Meski Luwu Timur memiliki banyak potensi budaya, namun tampaknya sulit untuk segera dikemas. Kecuali sudah dimulai dari sekarang revitalisasi dan pelestarian budaya lokal yang beragam (Proto Melayu: orang Padoe, orang Toraja dan orang Pamona kebanyakan di pegunungan. Deutro Melayu: orang Bugis kebanyakan di daerah pesisir dengan epos agung I La Galigo).

Ketika pandemi covid-19 terjadi memasuki tahun 2020, pariwisata Luwu Timur tampak tidak terganggu. Pasarnya adalah masih pengunjung lokal dan warga kabupaten lain di sekitar Luwu Timur. Terjadi penataaan infrastruktrur di beberapa daya tarik wisata pantai yang dianggap potensial oleh pemkab Luwu Timur.

Pada tahap perkenalan dipersiapkan kematangan masyarakat lokal terutama di daya tarik wisata untuk memiliki motivasi positif dan menciptakan iklim persaingan harmonis dengan sedini mungkin meminimalkan terjadinya konflik. Beberapa daya tarik wisata dan produk wisata sudah mulai dirasakan manfaat ekonomi dan mulai timbul persaingan-persaingan (ciri-ciri akan memasuki tahap reaksi).

Sehingga pemkab Luwu Timur harus semakin tanggap untuk menciptakan regulasi, fasilitasi dan sosialisasi pariwisata. Terutama tentang sadar wisata (Sapta Pesona), mempersiapkan SDM pariwisata, perencanaan berbasis pariwisata berkelanjutan, dan sumbersumber pendapatan pariwisata badi daerah.

\section{Upaya Refleksi Turismemorfosis}

Masing-masing tahapan turismemorfosis memiliki problematika terkait dengan faktor internal dan faktor eksternal. Perkembangan pariwisata sebagai suatu perubahan tidak dapat dipisahkan dari kemampuan discovery, invention, pengaruh difusi dan pengaruh globalisasi. Paradigma, diskursus/wacana, aktor dan institusi penopang/kelembagaan menjadi menarik karena merupakan titik temu dari faktor internal (kapasitas aktor, keadaan sosial, budaya, politik, ekonomi, hukum, keamanan dan kondisi lingkungan) dan faktor eksternal (aktor-aktor luar pemegang kekuasaan dan modal ekonomi, difusi / persebaran budaya, globalisasi, kapitalismekonglomerasi global, neo liberalisme, standarisasi global dan pasar global).

Saling tarik menarik antara nilai kelokalan dan nilai budaya barat yang dianggap maju-diakui sebagai nilai global terjadi. Pariwisata budaya di Badung (Bali) adalah contoh menariknya. Upaya yang dilakukan oleh Pemkab Banyuwangi dengan melakukan event-event budaya tradisional dengan kekuatan brand melalui medsos juga contoh lain. Pemkab Luwu Timur yang tibatiba memilih sektor pariwisata sebagai fokus adalah contoh luar biasa.

Ketika faktor eksternal menghegemoni atau bahkan mendominasi suatu destinasi wisata maka keran investasi untuk mencapai pertumbuhan ekonomi dan peningkatan pendapatan daerah maupun kesejahterahaan masyarakat lokal secata instan biasanya terjadi. Investor-investor luar akan masuk dengan kepentingan bisnis (market trend) dan akan sangat terlihat terjadi eksploitasi. Secara ekonomi pasti akan sangat positif, tetapi di sisi lain degradasi budaya, potensi konlik sosial 
dan indikasi kerusakan lingkungan akan berdinamika (secara umum keadaan ini terjadi pada tahap pelembagaan).

Kompromi menjadi jalan tengah dan bahkan lebih dapat disebut sebagai hegemoni seperti di Badung (berbeda dengan di Banyuwangi sebagai dominasi). Apa pun dapat dilakukan untuk pariwisata karena menguntungkan secara ekonomi, tetapi terdapat intrik-intrik, persuasif atau jalinan komunikasi maupun aksi yang terlihat saling menguntungkan (padahal belum tentu). Modal ekonomi menjadi jawaban, karena jika memiliki modal ekonomi besar maka modal lainnya seperti modal simbolik, modal sosial dan modal budaya akan mengikutinya. Atau, ketika kekuasaan diperoleh karena kekuatan ekonomi oleh aktor-aktor pariwisata global maka kompromi dapat dilakukan dengan membaca, berstrategi dan menyikapi kondisi sosial budaya masyarakat lokal untuk mencapai tujuan utama yaitu keuntungan bisnis.

\section{SIMPULAN DAN SARAN SIMPULAN}

Berdasarkan analisis turismemorfosis Kabupaten Badung berada pada tahap kompromi, kabupaten Banyuwangi pada tahap pelembagaan dan kabupaten Luwu Timur pada tahap perkenalan. Perkembangan pariwisata tersebut sebagai suatu dinamika dapat digunakan untuk perencanaan dan pengembangan pariwisata kedepan. Sehingga pengembangan berbasis perkembangan pariwisata akan mampu meminimalkan terjadinya dampak-dampak negatif pariwisata.

\section{Recomendation} yaitu:

Beberapa rekomendasi dapat disampaikan

1. Pariwisata di kabupaten Badung harus mulai memperhatikan potensi lokal karena terkait dengan masa depan pariwisata / keberlanjutan pariwisata bagi generasi penerus. Kompromi dengan investor untuk pembangunan pariwisata di tingkat desa dilakukan tidak hanya untuk kepentingan ekonomi, melainkan kelestarian lingkungan dan penguatan budaya lokal yang fleksibel.

2. Pariwisata di kabupaten Banyuwangi memiliki kekuatan pada potensi alam.
Potensi budaya dapat dipilih, tetapi lebih kepada pelengkap untuk menunjang potensi alam yang memiliki kekuatan besar sebagai penarik wisatawan.

3. Pariwisata di kabupaten Luwu Timur meskipun memiliki ragam potensi budaya, tetapi tampak akan lebih menjanjikan untuk berfokus kepada wisata alam, ekowisata, agrowisata dan wisata minat khusus (wisata tambang). 


\section{Kepustakaan}

Anom, I Putu, Mahagangga, I Gusti Agung, Nugroho, Saptono dan Suryasih, Ida Ayu. 2016. Problematikan Pariwisata Bali, Membangun Paradigma Pariwisata Bali Masa Depan. Laporan Penelitian yang tidak dipublikasikan, Hibah Unggulan Udayana. Bukit Jimbaran: LPPM Universitas Udayana

Anom, I., Suryasih, I., Nugroho, S., \& Mahagangga, I. (2017). Turismemorfosis: Tahapan selama seratus tahun perkembangan dan prediksi pariwisata Bali. Jurnal Kajian Bali (Journal Of Bali Studies), 7(2), 59-80. doi:10.24843/JKB.2017.v07.i02.p04

Anoma, I. P., Mahaganggab, I. G. A. O., \& Suryawanc, I. B. 2020. Emerging Transdisciplinary Theory on Tourism Research: A Case from Bali. practice, 11(1).

Anom, M. Par., Dr. Drs. I Putu dan Mahagangga, S.Sos., M.Si, I Gusti Agung Oka. 2020. Handbook Ilmu Pariwisata Karakter dan Prospek. Jakarta: Prenada Media (Divisi Kencana).

Anom, M. Par., Dr. Drs. I Putu dan Mahagangga, S.Sos., M.Si, I Gusti Agung Oka. 2020. Spektrum Ilmu Pariwisata Mitos Sebagai Modal Budaya Dalam Pengembangan Pariwisata Bali. Jakarta: Divisi Kencana (Prenada Media Group).

Arief. 2009. Pengetahuan dan Metode: Karyakarya Penting MichelFoucault. Yogyakarta: Jalasutra

Bachtiar, H.W. 1983. Pengamatan Sebagai Suatu Metode Penelitian dalam Metode-Metode Penelitian Masyarakat, Koenjaraningrat (Ed.). Jakarta: Gramedia.

Becherel, Lionel., Vellas, Francois. 2008. PemaRecomendation Pariwisata Internasional. Jakarta: Yayasan Obor Indonesia.

Beatty, A. (2012). "Kala defanged Managing power in Java away from the centre". Bijdragen tot de Taal-, land-en Volkenkunde, 168(2/3), 173-194. google scholaar link.

Butler, R. W. 1980. The concept of a tourist area cycle of evolution: implications for managementofresources. Canadian Geographer/Le Géographe canadien, 24(1), 5-12. Google Scholaar Link.

Butler, R. (2015). The evolution of tourism and tourism research. Tourism Recreation Research, 40(1), 16-27.

Cheong, S. M., \& Miller, M. L. (2000). Power and tourism: A Foucauldian observation. Annals of tourism research, 27(2), 371-390.
Dipadewanda, I Made. 2018. Perkembangan Pariwisata Desa Bongkas Menuju Desa Wisata. Laporan penelitian yang tidak dipublikasikan Skripsi S1 Prodi Destinasi Pariwisata. Denpasar: Fakultas Pariwisata Universitas Udayana.

Dreyfus, H., and P. Rabinow 1982 Michel Foucault: Beyond Structuralism and Hermeneutics. Chicago: Harvester, University of Chicago Press

Fidler R (1997) Mediamorphosis: Understanding New Media. Thousand Oaks: Pine Forge Press.

Fridgen, J. D. (1990). Dimensions of tourism. Educational Institute of the American Hotel \& Motel Association.

Geertz, C. 1973. The Interpretation of Culture. New York: Basic Books.

Geria, I Wayan. 2000. Transformasi Kebudayaan Bali Memasuki Abad XXI. Denpasar Percetakan Bali.

Goodson, L., \& Phillimore, J. (Eds.) 2004. Qualitative research in tourism: Ontologies, epistemologiesandmethodologiesRoutledge.

Goolaup, S., \& Solér, C. (2018). Existentialphenomenology: Understanding tourists' experiences. In Handbook of research methods for tourism and hospitality management. Edward Elgar Publishing.

Greenwood, D. J. (1972). Tourism as an agent of change: A Spanish Basque case. Ethnology, 11(1), 80-91.

Hutabarat, H., \& Mahagangga, I. G. A. O. 2019. Perkembagan Wisata Mendaki Di Gunung Agung: Studi Kasus Gunung Agung, Kabupaten Karangasem, Provinsi Bali. Jurnal Destinasi Pariwisata 7 (2), 218-225.

Jati, K. N. 2019. Perancangan Website Sosiohistori Pariwisata Bali. Laporan penelitian yang tidak dipublikasikan Skripsi S1 Seni Rupa. Yogyakarta: ISI Yogyakarta

JENNINGS, GR. 2018 "Qualitatative Research and Tourism Studies. In Handbook of Tourism Management Theories, Concepts and Diciplinary Approaches to tourism, Qualitative Research and Tourism Studies". Chris Cooper, Serena Volo, William C. Gartner \& Noel Scott (eds.). SAGE.

Karsidi, R. (2001). Paradigma Baru Penyuluhan Pembangunan dalam Pemberdayaan Masyarakat. Mediator:Jurnal Komunikasi, 2(1), 115-125.

Koenjaraningrat. 1997. Metode-Metode Penelitian Ilmu Sosial. Jakarta: Rajawali. 
Lekkerkerker, C. (1923). HET OUD SPAANSCH KOLONIAAL STELSEL ZOOALS DIT IS NEDERGELEGD IN DE. Bijdragen tot de Taal-, Land-en Volkenkunde, 79(1), 198. google scholar link

Mahagangga, I., \& Oka, G. A. Suryawan, Ida Bagus. Anom, I Putu dan Kusumanegara, I Made. 2018. Evolusi Pariwisata di Indonesia, Turismemorfosis di Kabupaten Badung, Kabupaten Banyuwangi dan Kabupaten Luwu Timur.

Mahagangga, dkk., 2020. Fenomena Masa Jeda Pariwisata Bali (Suatu Studi Pustaka) dalam Pemikiran Kepariwisataan Masa Jeda Pariwisata untuk Bangkit Kembali (Editor Dian Pramita Sugiarti, dkk.) Ponorogo: Uwais Inspirasi Indonesia.

Maria, N. (2017). GERAKAN SOSIAL POLITIK DI BLAMBANGAN TAHUN 17671768. Patanjala: Jurnal Penelitian Sejarah dan Budaya, 9(3), 407-422. google scholar link.

Moleong, L. J. (2005). Metodologi Penelitian Kualitatif, Bandung: Remaja Rosdakarya.

Nordholt, H. S., Purwanto, B., \& Saptari, R. (Eds.). 2009. Perspektif baru penulisan sejarah Indonesia. Jakarta: Yayasan Obor Indonesia.

Noronha, R. 1977. Social and cultural dimensions of tourism: A review of the literature in English. Washington DC: World Bank (Draft)

Noronha, R. (1979). Paradise reviewed: tourism in Bali (pp. 177-204). Oxford University Press for World Bank and UNESCO.

Nugraha, Iskandar P. 2000. "Dutch politics of seeing; Tourist guidebooks in colonial Indonesia". Makalah tidak diterbitkan

Pabbajah, M. (2012). Ali Fadillah, dan Iwan Sumantri (ed). Kedatuan Luwu:Perspektif Arkeologi, Sejarah dan Antropologi. "RELIGIUSITAS

\section{DANKEPERCAYAANMASYARAKAT}

BUGISMAKASSAR". AlUlum,12(2), 397-418. Makassar:Lembaga
Penerbitan Universitas Hasanuddin atas kerja sama dengan Institut Etnografi Indonesia

Pernecky, T., \& Jamal, T. 2010. (Hermeneutic) phenomenology in tourism studies. Annals of Tourism Research, 37(4), 1055-1075.

Picard, Michel. 2006. Bali : Pariwisata Budaya dan Budaya Pariwisata (terj.) Jakarta: KPG (Kepustakaan Populer Gramedia)

Pitana, I Gde. 2002. Pariwisata, Wahana Pelestarian Kebudayaan dan Dinamika Masyarakat Bali. Pidato Pengukuhan Guru Besar bidang Sosial Pariwisata. Denpasar : Universitas Udayana
Richards, G., \& Munsters, W. (Eds.). 2010 Cultural tourism research methods. Cabi.

Raharjo, Supratikno dan Munandar, Agus Aris. 1998. "Dampak Pariwisata Terhadap Kebudayaan Bali”. Susanto Zuhdi (ed). Sejarah Kebudayaan Bali : Kajian Pengembangan dan Dampak Pariwisata Jakarta : Departemen Pendidikan dan Kebudayaan RI.

Rusdianto, Eko. 2011.“Desa Pandai Besi yang Hilang" November 2011. Pukul 01.00. https://historia.id/budaya/articles/desapandai-besi-yang-hilang-v23QP

Saputra, D., Krisna Juliharta, I., \& Wahyu Nirmala, B. (2020). Implementasi Sistem Informasi Muselok Menggunakan Augmented Reality Berbasis Android. JURNAL DESTINASI PARIWISATA, $\quad 8(1), \quad$ 159-168. doi:10.24843/JDEPAR.2020.v08.i01.p21

Stockdale, John Joseph. 2017. The Island of Java, Sejarah Tanah Jawa (Terjemahan). Yogyakarta : Indoliterasi

Sugiharto, I.B. 1996. Postmodernisme: Tantangan Bagi Filsafat. Yogyakarta: Kanisius.

Sugiyono, A. G. 2005. Memahami Penelitian Kualitatif Bandung: CV. Alfabeta

Syukur, S. (2015). Sistem Pemerintahan Kedatuan Luwu dalam Kurung Periode I Lagaligo(AbadIXXIII). RIHLAH, 3(01), 25-34. Makasar: Fakultas Adab dan Humaniora, UIN Alauddin. google scholar link.

Wijayanto, E. 2013. Memetika sebagai Studi Kebudayaan Berbasis Evolusi. MELINTAS 29 (1), 42-55. google scholar link.

Zed, M. 2004. Metode Penelitian Kepustakaan. Jakarta: Yayasan Obor Indonesia. 